JOURNAL OF

HORTICULTURAL

SCIENCES
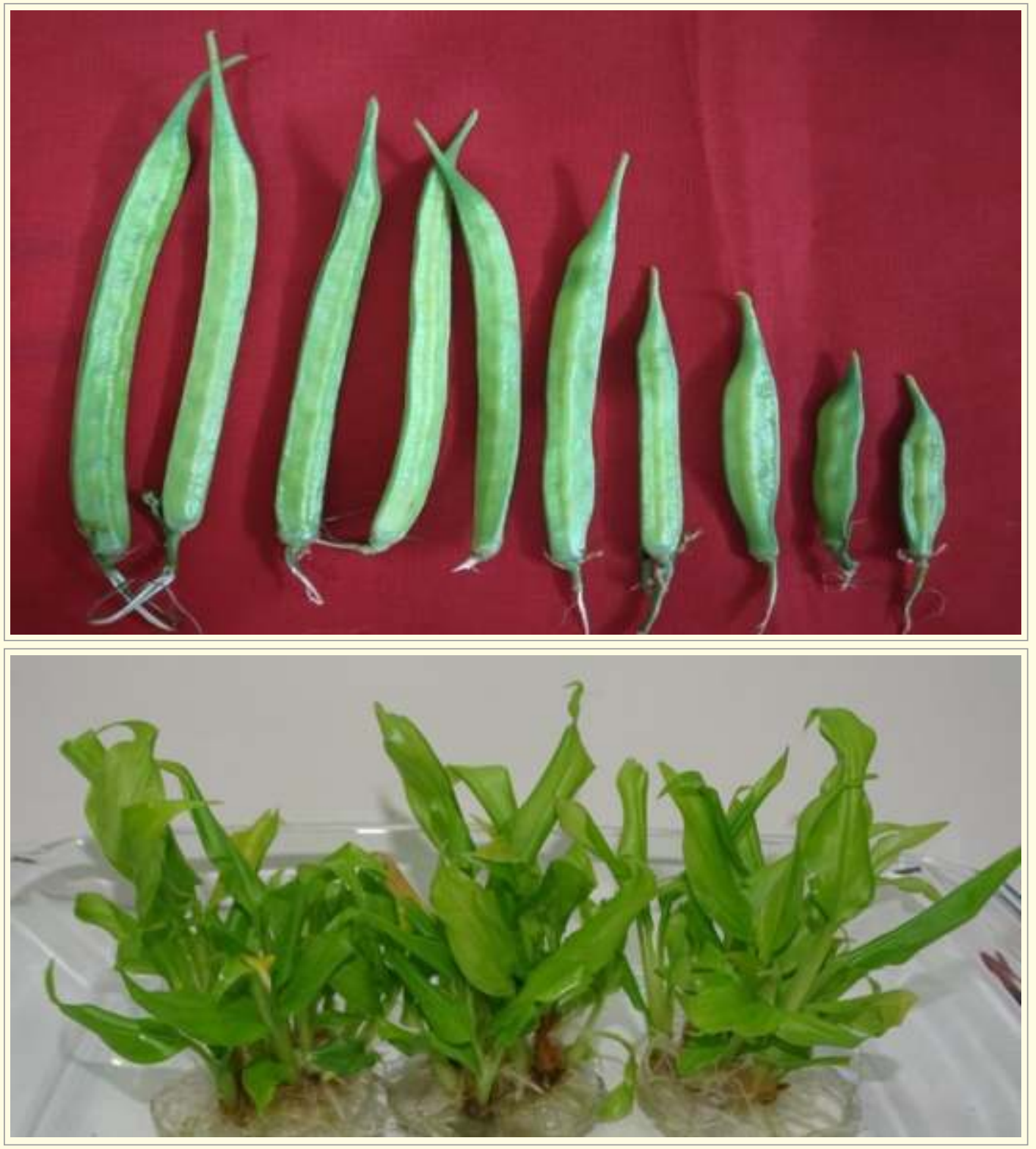

Society for Promotion of Horticulture

ICAR - Indian Institute of Horticultural Research, Bengaluru - 560089 


\section{JOURNAL OF HORTICULTURAL SCIENCES}

\section{ONTENTS}

\section{In this Issue}

\section{Review}

Moringa (Moringa oleifera L.): An underutilized and traditionally valued

tree holding remarkable potential

Jattan M., Kumari N., Raj Kumar, Kumar A., Rani B., Phogat D.S.,

Kumar, S. and Kumar, P.

\section{Original Research in Papers}

Characterization and evaluation of mountain sweet thorn

(Flacourtia montana J. Grah) collections

Tripathi P.C., Ganeshan S., Radhika V. and Shetti D.L.

Optimization of methodology for the extraction of polyphenolic compounds

with antioxidant potential and á-glucosidase inhibitory activity from jamun

(Syzygium cumini L.) seeds

Arivalagan M., Priyanka D.R. and Rekha A.

Genetic variability studies in amaranthus (Amaranthus spp.)

Agadi A.H., Kolakar S., Lakshmana D., Nadukeri S. and Hanumanthappa M.

Morpho-physiological parameters associated with chlorosis resistance to

iron deficiency and their effect on yield and related attributes in potato

(Solanum tuberosum L.)

Challam C., Dutt S., Sharma J., Raveendran M. and Sudhakar D.

Responses of different Okra (Abelmoschus esculentus) cultivars to water

deficit conditions

Ayub Q., Khan S.M., Hussain I., Naveed K., Ali S., Mehmood A., Khan M.J., Haq N.U., Shehzad Q.

Induced variability for yield and its attributing traits in cluster bean

[Cyamopsis tetragonoloba (L. ) Taub] through gamma irradiation

Lavanya H.N., Mishra S., Sood M., Aghora T.S., Anjanappa M., Rao V.K. and Reddy A.B.

In vitro multiplication protocol for Curcuma mangga : Studies on carbon,

Waman A.A., Bohra P., Karthika Devi R. and Pixy J. 
Effect of fungicide and essential oils amended wax coating on quality and shelf life of sweet orange (Citrus sinensis Osbeck)

Bhandari M., Bhandari N. and Dhital M.

Post-harvest quality and quantification of betalains, phenolic compounds and antioxidant activity in fruits of three cultivars of prickly pear

(Opuntia ficus-indica L. Mill)

Gonzalez F.P.H., Saucedo V.C., Guerra R.D., Suarez E.J., Soto H.R.M. Lopez J.A.,

Garcia C.E. and Hernandez R.G.

Soil microbial community dynamics as influenced by integrated nutrient management practices in sweet basil (Ocimum basilicum L.) cultivation Baraa AL-Mansour and D. Kalaivanan

Effect of spectral manipulation and seasonal variations on cut foliage production and quality of Philodendron (Philodendron 'Xanadu')

Sujatha A. Nair, Laxman R.H. and Sangama

\section{Short Communications}

Studies on mutagenic sensitivity of seeds of pummelo (Citrus maxima Merr.)

Sankaran M., Kalaivanan D. and Sunil Gowda D.C.

Isolation and characterization of microsatellite markers from

Garcinia indica and cross species amplification

Ravishankar K.V., Vasudeva R., Hemanth B., Nischita P., Sthapit B.R.,

Parthasarathy V.A. and Rao V.R. 


\title{
Effect of spectral manipulation and seasonal variations on cut foliage production and quality of Philodendron (Philodendron 'Xanadu')
}

\author{
Sujatha A. Nair*, Laxman, R. H. and Sangama \\ ICAR- Indian Institute of Horticultural Research, Bengaluru, Karnataka, India. \\ *Corresponding author e-mail: SujathaA.Nair@icar.gov.in
}

\begin{abstract}
Influence of spectral manipulation of light using coloured nets and seasonal variation on cut foliage yield and quality of Philodendron 'Xanadu' was evaluated under red, green, white and black coloured shade nets permitting light intensities ranging from 240.50 to $370 \mu \mathrm{mol} \mathrm{m}^{-2} \mathrm{~s}^{-1}$ (75\% shade net), for two consecutive years from 2014-16, at ICARIIHR, Bengaluru. The plants grown under white shade net $(75 \%$ shade) resulted in higher foliage production plant ${ }^{-1}$ month $^{-1}(14.53)$ and were on par with those grown under green shade net. The quality of the cut foliage in plants grown under white shade net with respect to stalk length $(24.91 \mathrm{~cm})$ and width of lamina $(5.19 \mathrm{~cm})$ was on par with those under green and black shade nets. Coloured shade nets did not influence vase life of the cut foliage. Developmental stages of the foliage under the different coloured nets have indicated that leaves attained the harvestable maturity stage at 29.92 days post emergence under white shade. Cultivation of Philodendron 'Xanadu' under white shade resulted in maximum cut foliage yield and quality.
\end{abstract}

Key words : Coloured shade nets, Cut foliage, Philodendron 'Xanadu' and Photomorphogenesis

\section{INTRODUCTION}

Philodendron 'Xanadu' is a perennial evergreen tropical shrub, which belongs to the family Araceae and is cultivated under partial shade for its glossy green foliage. The cut foliage is used in floral bouquets as fillers and in floral arrangements. Coloured shade nets are used to regulate the crop growth and quality by screening various spectral bands of the solar radiation. According to Shahak (2008), the spectral manipulation by use of coloured nets influences the microclimate to which the plant is exposed, and promotes light-regulated desirable physiological responses, besides the nets providing physical protection against excessive radiation, insect pests and environmental changes. Stuefer and Huber (1998) opined that changes in light composition influence the development and morphogenesis. Photomorphogenesis is influenced by phytochromes (Quail et al., 1995), cryptochromes (Ahmad and Cashmore, 1996; Batschauer, 1998), and specialized UV-A and UV-B (Christie and Jenkins, 1996) receptors, about which little is known. Mohr (1994) reported that in many of the photomorphogenetic reactions, more than one photoreceptor is involved. Coloured shade nets induce desirable physiological responses and this is related to the production and quality of the crop. According to Ganelevin (2008), this is an economical and environmentally friendly alternative to labour and chemical intensive crop production and is being assessed in an increasingly growing number of crops, leading to gradual expansion of the commercial use. Many of the cut greens are commercially grown in India under green or black shade nets. A study was conducted to evaluate the coloured shade net most suitable for commercial production of Philodendron 'Xanadu' cut foliage, with the objective of exploring the possibility of improving the yield and quality.

\section{MATERIALS AND METHODS}

An experiment was conducted at the Division of Flower and Medicinal Crops, ICAR-Indian Institute of Horticultural Research, Bengaluru during 2014 to 2016 on Philodendron 'Xanadu' grown under four coloured polypropylene shade nets $(75 \%)$ viz., red, 
black, green and white in randomised block design with six replications. Healthy, uniform suckers of Philodendron 'Xanadu' were planted on raised beds at $45 \mathrm{x} 45 \mathrm{~cm}$ spacing. Well decomposed FYM was added to the beds@2 $\mathrm{kg} \mathrm{m}^{-2}$ and was thoroughly mixed. Fertilizers were applied to the plants @ 100:30:60 kg NPK ha-1 per year. Entire dose of phosphorous was supplied as basal dose and nitrogen and potash were applied in six equal split doses at bimonthly intervals. Observations on the number of cut foliage plant ${ }^{-1}$ month $^{-1}$, length of lamina, length of stalk, frond width and diameter of stalk were recorded. Based on the importance with regard to marketable standards, some of these parameters were assigned a factor with which it was multiplied and the weighted averages were calculated.

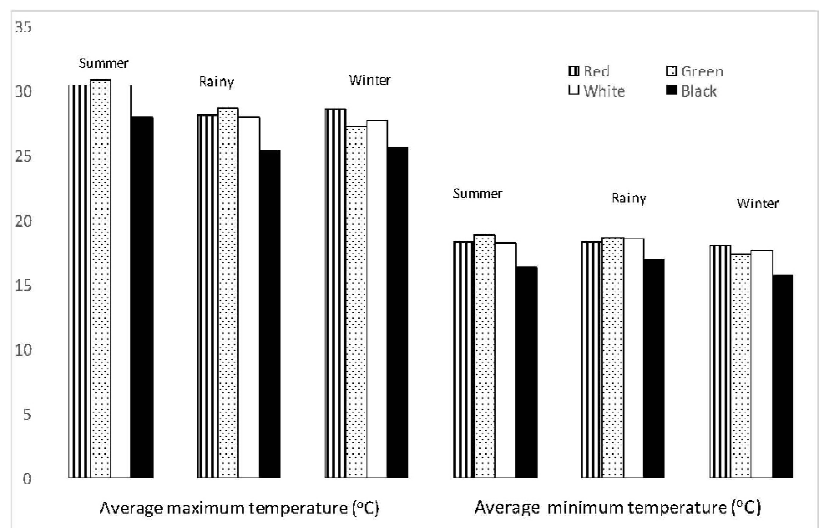

Fig. 1a: Maximum and minimum temperatures $\left({ }^{\circ} \mathrm{C}\right)$ inside coloured shade nets during different seasons

\section{RESULTS AND DISCUSSION}

Data pertaining to the influence of coloured shade nets on production and quality of the cut foliage of Philodendron 'Xanadu' have been presented in Table 1. Plants grown under white shade nets produced the maximum number of cut foliage plant ${ }^{-1}$ month $^{-1}(14.53)$ which was on par with those grown under green shade net (13.71) followed by plants under red net (13.31). Minimum yield of cut foliage plant ${ }^{-1}$ month $^{-1}$ was obtained under black shade net (10.36). However, Stamps (2008) recorded the maximum foliage production under red shade net in Philodendron 'Xanadu'. In this study, the foliage production was highest under white shade net which might be due to the higher PAR availability. The foliage quality was significantly influenced by the colour of the shade nets. Plants grown under black shade net recorded
Developmental stages of the foliage, epicuticular wax content of the foliage and post harvest qualities under the diffrerent coloured shade nets were recorded. The gas exchange parameters, net photosynthesis $\left(P_{\mathrm{N}}\right)$, transpiration rate $(E)$ and stomatal conductance $(g \mathrm{~s})$ were recorded between 09:30 $\mathrm{h}$ and 11:00 h on fully expanded fourth leaf from shoot apex using portable photosynthetic system (LC pro+, ADC Bioscientific limited, UK). Seasonal influence on the production and quality attributes of the foliage was also analysed. The pooled data were statistically analysed (Gomez and Gomez, 1984) and the results have been presented. The average maximum and minimum temperatures and relative humidity recorded under the different coloured shade nets during the experimental period have also been presented in Figs. $1 \mathrm{a}$ and $1 \mathrm{~b}$.

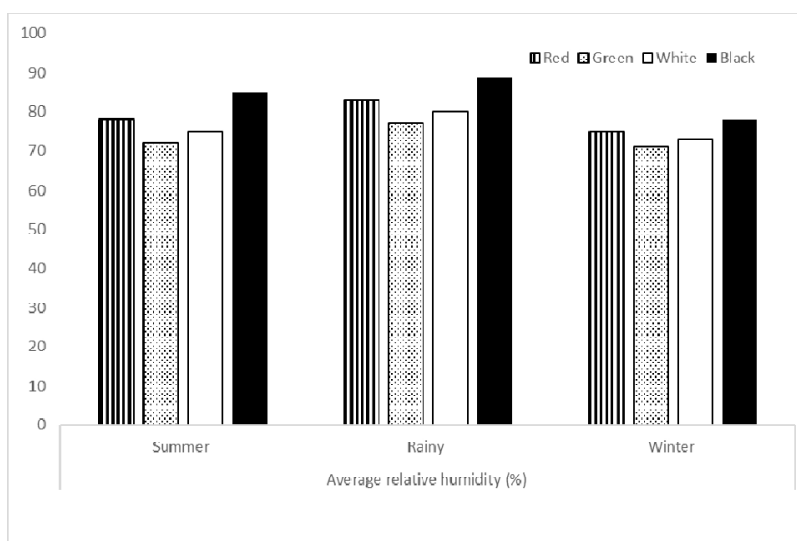

Fig. 1b: Seasonal effect on the relative humidity (\%) inside coloured shade nets

maximum length of stalk $(26.27 \mathrm{~cm})$, which was on par with green $(25.86 \mathrm{~cm})$, white net $(24.91)$ and was minimum in red $(22.95 \mathrm{~cm})$. Cultivation of plants under green shade net resulted in the maximum average width of lamina $(5.36 \mathrm{~cm})$ which was on par with black $(5.23 \mathrm{~cm})$, white $(5.19)$ and it was minimum in red $(4.97 \mathrm{~cm})$. Cultivation of plants under green shade net resulted in maximum stalk diameter $(5.11 \mathrm{~mm})$ and was minimum in black nets $(4.49 \mathrm{~mm})$.

The seasonal influence on cut foliage production and quality of Philodendron 'Xanadu' during three seasons viz, summer (March to June), rainy (July to October) and winter (November to February) was analysed and graphically presented in Figs. 2(a-e).

During rainy season, the cut foliage production plant $^{-1}$ was higher in the plants grown under all the coloured nets as compared to summer and winter 
Table 1: Influence of shade net colour on the production and quality of cut foliage in Philodendron 'Xanadu'

\begin{tabular}{|l|c|c|c|c|c|}
\hline $\begin{array}{l}\text { Treatment } \\
\text { (Shade net } \\
\text { colour) }\end{array}$ & $\begin{array}{c}\text { Number of } \\
\text { foliage/plant/ } \\
\text { month }\end{array}$ & $\begin{array}{c}\text { Length of } \\
\text { lamina } \\
\text { (cm) }\end{array}$ & $\begin{array}{c}\text { Length of } \\
\text { stalk } \\
\text { (cm) }\end{array}$ & $\begin{array}{c}\text { Average } \\
\text { lamina width } \\
\text { (cm) }\end{array}$ & $\begin{array}{c}\text { Diameter of } \\
\text { stalk } \\
\text { (mm) }\end{array}$ \\
\hline Red & 13.31 & 15.23 & 22.95 & 4.97 & 4.67 \\
\hline Green & 13.71 & 15.70 & 25.86 & 5.36 & 5.11 \\
\hline White & 14.53 & 15.24 & 24.91 & 5.19 & 4.74 \\
\hline Black & 10.36 & 14.70 & 26.27 & 5.23 & 4.49 \\
\hline SEm \pm & 0.40 & 0.30 & 0.38 & 0.87 & 0.10 \\
\hline $\mathrm{CD}(\mathrm{P}=0.05)$ & 1.17 & $\mathrm{NS}$ & 1.12 & 0.25 & 0.3 \\
\hline
\end{tabular}

seasons. The cut foliage production plant ${ }^{-1}$ month $^{-1}$ (Fig. 2) was maximum in plants grown under white shade net during rainy season (19.54) and minimum in plants grown under black shade net during summer (9.01). Production of foliage was at par during the summer and winter seasons. Foliage quality was influenced to a certain extent by seasonal variations for characters like length of lamina, length of stalk, average width of lamina and diameter of stalk across the colour of the nets. The quality of cut foliage harvested from plants grown under green shade nets was superior for length of lamina $(15.68 \mathrm{~cm}, 15.77$ $\mathrm{cm}$ and $15.65 \mathrm{~cm}$ during summer, rainy and winter seasons, respectively), length of stalk $(28.26 \mathrm{~cm}$ during rainy season), lamina width $(5.52 \mathrm{~cm}$ during summer season) and diameter of stalk (7.30 $\mathrm{mm}$ during winter season). The quality attributes of the foliage grown under white shade nets in respect of length of lamina $(14.97 \mathrm{~cm})$ and length of stalk $(25.60 \mathrm{~cm})$ during winter months and width of lamina during summer months $(5.18 \mathrm{~cm})$ were at par with that of the green nets. In general, the quality parameters of the foliage were lower under red and black nets depending on the season.

The per cent available Photosynthetically Active Radiation (PAR) inside the green coloured nets was highest (35.45\% during summer, $41.54 \%$ during rainy season and $38.16 \%$ during winter season), followed by the PAR inside white coloured nets $(29.09 \%$ during summer, $31.75 \%$ during rainy season and $35.04 \%$ during winter season). PAR designates the spectral range of solar radiation from 400 to 700 nanometres that plants are able to use in the process of photosynthesis. Higher PAR might have contributed to increase in photosynthesis by the plants, production of more photosynthates, thereby resulting in increased production of foliage. The quality of foliage like longer lamina, stalk and width of lamina could be correlated with the increase in sink capacity due to production of more photosynthates.

Epicuticular wax content (EWC) of the foliage was estimated and presented in Fig.5. EWC in the foliage of plants grown under green shade net was 871.8 $\mu \mathrm{gdm}^{-2}$ whereas the plants under white nets recorded $800.2 \mu \mathrm{gdm}^{-2}$. EW strongly contributes to the maintenance of high photosynthetic rates on leaves, which are able to keep their stomata open for longer periods, with high water use efficiency (Medeiros et al., 2017).

The vase life of cut foliage was evaluated under room condition (temperature $24-28^{\circ} \mathrm{C}$ and $50-67 \% \mathrm{RH}$ ) in distilled water and it did not vary significantly among the cut foliage grown under different shade net colours (Fig 3) which was in accordance with the findings of Stamps (2008) in Philodendron 'Xanadu'.

The developmental stages of Philodendron (Fig. 4) were studied and the days taken by the foliage to attain each of the three critical stages i.e., Stage 1 (leaf tightly rolled in cataphyll), Stage 2 (just expanded tender leaf) and Stage 3 (fully expanded matured leaf) under the different shade nets were recorded. The days taken for progression from the first to second stage did not show marked difference under the different coloured nets. Green shade net (30.83 days) followed by white shade net (29.92 days) was found to have increased time intervals for the attaining the fully expanded mature stage from the tender leaf stage as compared to black (28.00 days) and red 


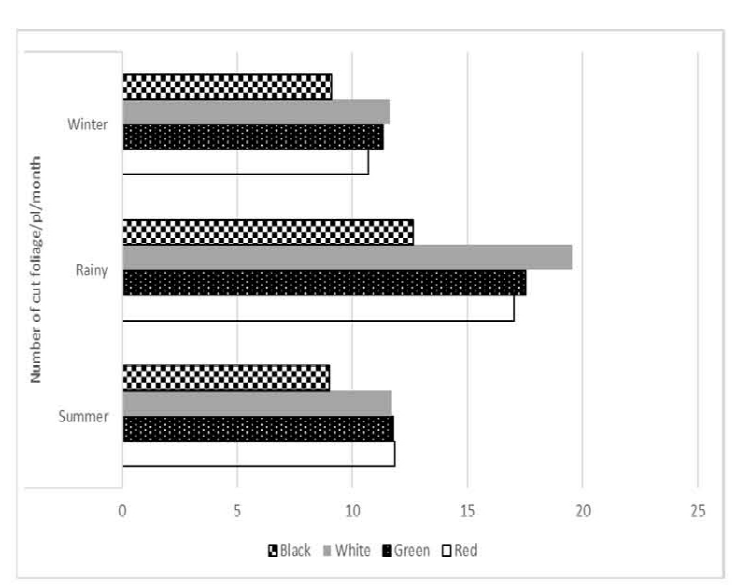

Fig. 2a. Number of foliage plant ${ }^{-1}$ month $^{-1}$

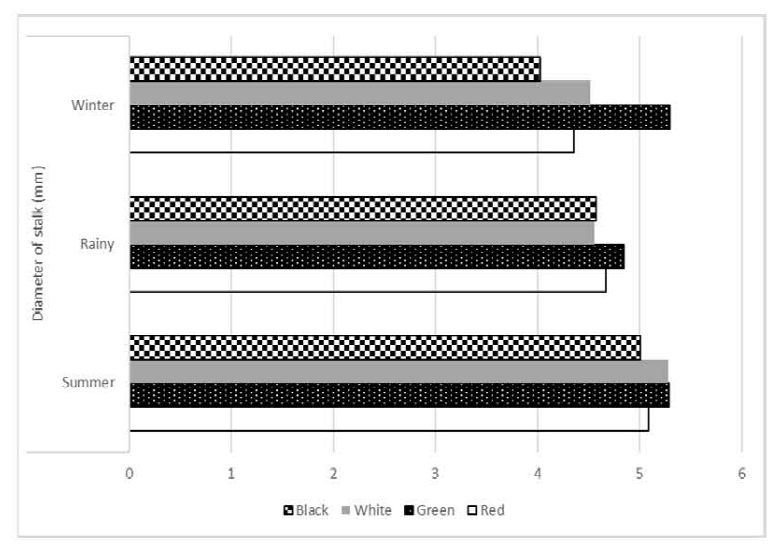

Fig. 2c. Diameter of stalk (mm)

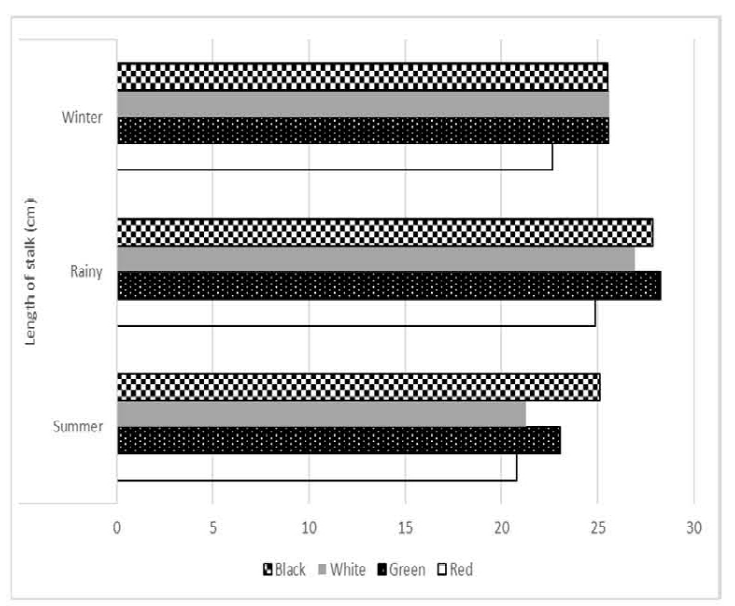

Fig. 2b. Length of stalk (cm)

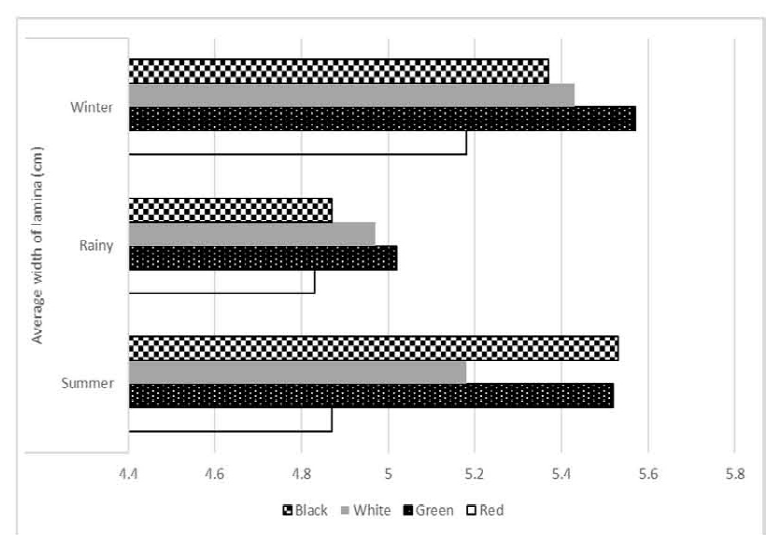

Fig. 2d. Width of lamina $(\mathrm{cm})$

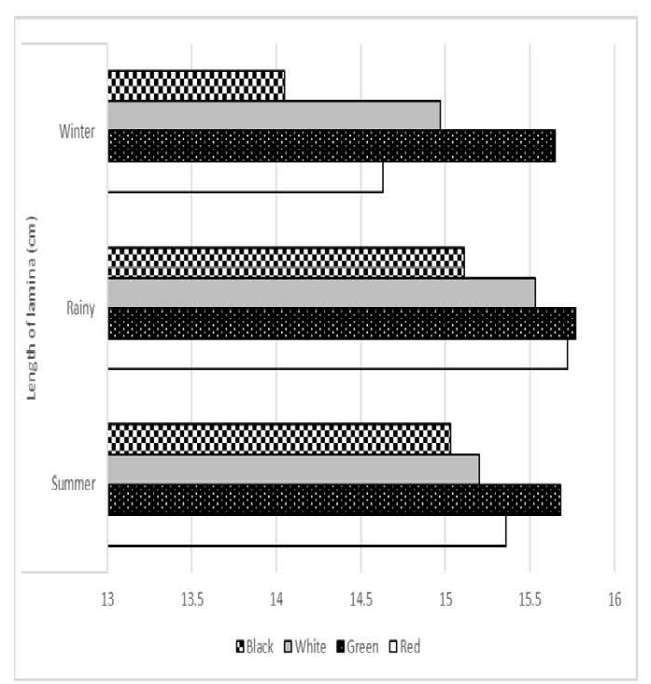

Fig. 2e. Length of lamina $(\mathrm{cm})$

Fig 2 (a-e). Influence of coloured shade nets and seasons on the cut foliage production and quality of foliage in Philodendron 'Xanadu' 
shade nets (26.08 days). This can be correlated with the quality of the foliage indicating that with the increase in time taken to attain maturity, the foliage would have accumulated more of photosynthates resulting in superior quality.

Observations on gas exchange characteristics were recorded from the plants grown under different shade net colours. The photosynthesis rate was highest under green shade net during rainy season, which was on par with white shade net (Table 2). During summer and winter seasons, highest photosynthesis rate was observed in the plants under red shade net and was on par with white shade net. Plants under black shade net showed consistently lower photosynthesis rates across the seasons. The per cent PAR availability under different shade nets varied with highest available PAR under the green shade net followed by white shade net and least PAR was available under the black shade net (Table 2). Though definite trend was not observed among the different shade net treatments, overall, the transpiration rate was higher during summer season compared to rainy and winter seasons. The stomatal conductance was higher during rainy season compared to summer and winter seasons. In this study, it was observed that due to lower PAR availability under black shade net compared to other colour shade net, the photosynthesis rate was also lower. Ayala-Tafoya et al. (2018) in their study on the influence of coloured shade nets on photosynthesis and yield of cucumber observed that black shade net provided higher level of shade to the plants. The availability of PAR as well as red and blue lights were lower under black shade net compared to the other colour shade net. Black and white shade nets are known to cause reduction in light quantity and provide shade, while red shade net has effect on changes in red light composition (Ayala-Tafoya et al., 2011; Lobos et al., 2012; Oliveira et al., 2016). Though the green shade net transmitted highest PAR among the shade nets, the photosynthesis rate was highest during rainy season but was lower during summer and winter seasons which might be correlated with the temperature coefficient of real assimilation.

The maximum and minimum temperatures recorded inside the coloured nets also varied with green recording the highest average maximum and minimum temperatures in summer and rainy seasons and red net the highest maximum and minimum temperatures during winter season (Fig. 1a). Black shade net recorded the lowest average maximum and minimum temperatures across the seasons. The highest relative humidity was recorded inside the black shade net across the seasons followed by red shade and lowest inside green net (Fig. 1b).

Table 2: Seasonal influence of shade net colour on transpiration rate $\left(\mathrm{m} \mathrm{mol} \mathrm{m}^{-2} \mathrm{~s}^{-1}\right)$, stomatal conductance $\left(\mathrm{mol} \mathrm{m}^{-2} \mathrm{~s}^{-1}\right)$, photosynthesis rate $\left(\mu \mathrm{mol} \mathrm{CO} \mathrm{m}^{-2} \mathrm{~s}^{-1}\right)$ and per cent available PAR

\begin{tabular}{|c|c|c|c|c|c|c|c|c|c|c|c|c|}
\hline \multirow{2}{*}{$\begin{array}{l}\text { Treat- } \\
\text { ment } \\
\text { (Shade } \\
\text { net } \\
\text { colour) }\end{array}$} & \multicolumn{3}{|c|}{ 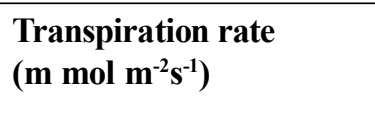 } & \multicolumn{3}{|c|}{$\begin{array}{l}\text { Stomatal } \\
\text { conductance } \\
\left(\mathbf{m o l ~ m}^{-2} \mathbf{s}^{-1}\right)\end{array}$} & \multicolumn{3}{|c|}{$\begin{array}{l}\text { Photosynthesis } \\
\text { rate } \\
\left(\mu \mathrm{mol} \mathrm{CO}_{2} \mathbf{m}^{-2} \mathbf{s}^{-1}\right)\end{array}$} & \multicolumn{3}{|c|}{$\begin{array}{l}\text { Per cent available } \\
\text { PAR }\end{array}$} \\
\hline & $\begin{array}{l}\text { Sum- } \\
\text { mer }\end{array}$ & Rainy & Winter & $\begin{array}{l}\text { Sum- } \\
\text { mer }\end{array}$ & Rainy & $\begin{array}{l}\text { Win- } \\
\text { ter }\end{array}$ & $\begin{array}{l}\text { Sum- } \\
\text { mer }\end{array}$ & Rainy & $\begin{array}{l}\text { Win } \\
\text { ter }\end{array}$ & $\begin{array}{l}\text { Sum- } \\
\text { mer }\end{array}$ & Rainy & $\begin{array}{l}\text { Win } \\
\text { ter }\end{array}$ \\
\hline Red & 6.22 & 3.36 & 3.02 & 0.18 & 0.30 & 0.17 & 9.44 & 10.44 & 9.13 & 26.58 & 31.69 & 27.58 \\
\hline Green & 4.84 & 3.58 & 3.29 & 0.12 & 0.31 & 0.20 & 7.59 & 11.64 & 7.21 & 35.45 & 41.54 & 38.16 \\
\hline White & 3.40 & 2.31 & 3.33 & 0.12 & 0.46 & 0.25 & 8.93 & 11.19 & 8.49 & 29.09 & 31.75 & 35.04 \\
\hline Black & 3.74 & 3.33 & 2.43 & 0.10 & 0.31 & 0.17 & 6.87 & 5.62 & 5.13 & 17.12 & 31.75 & 14.80 \\
\hline CV (\%) & 10.07 & 13.3 & 13.63 & 9.86 & 12.54 & 10.4 & 7.29 & 11.75 & 11.39 & 5.45 & 10.43 & 9.77 \\
\hline $\begin{array}{l}\mathrm{CD}(\mathrm{P}= \\
0.05)\end{array}$ & 1.82 & 0.83 & NS & 0.05 & 0.08 & NS & 1.19 & 2.28 & 1.70 & 1.88 & 4.3 & 3.39 \\
\hline
\end{tabular}




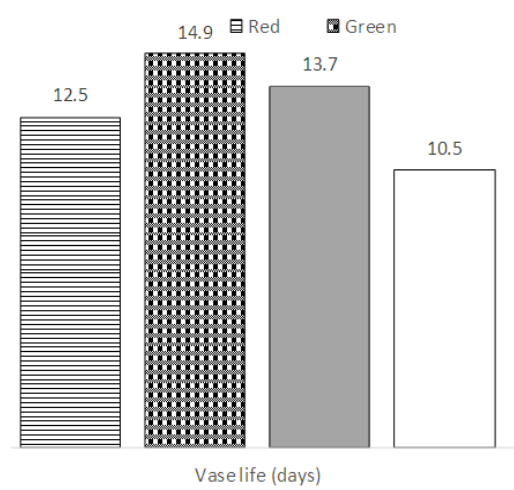

Fig. 3. Vase life of cut foliage of Philodendron 'Xanadu' cultivated under coloured shade nets

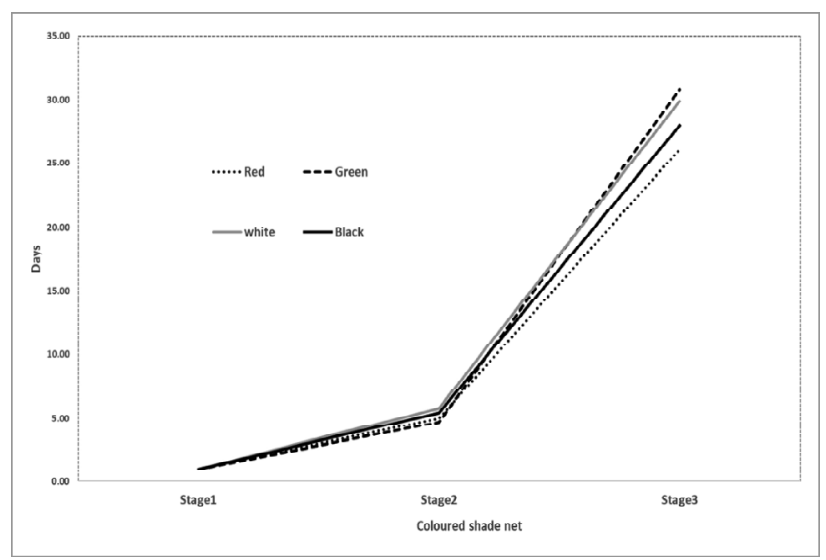

Fig. 4. Developmental stages of Philodendron

'Xanadu' foliage under coloured shade nets

Stage 1- Leaf rolled in cataphyll

Stage 2- Just expanded tender leaf

Stage 3- Fully expanded matured leaf

Weighted averages were assigned for the different characters of commercial importance according to the market standards (Fig. 6). White shade net grown cut foliage had the maximum weighted average (91.37) followed by green net (86.87), red net (84.32) and the least for cut foliage grown under black shade net (68.38).

Incidence of pests and diseases was monitored at weekly intervals. The plants remained relatively pest and disease free. Infestation of aphids was observed during the last week of March 2016, with the white shade net recording maximum number (18.35 per leaf) followed by red net (14.38 per leaf). Minimum infestation of 0.38 aphids per leaf was recorded on plants grown under black shade net. Incidence of Cercospora Leaf spot was

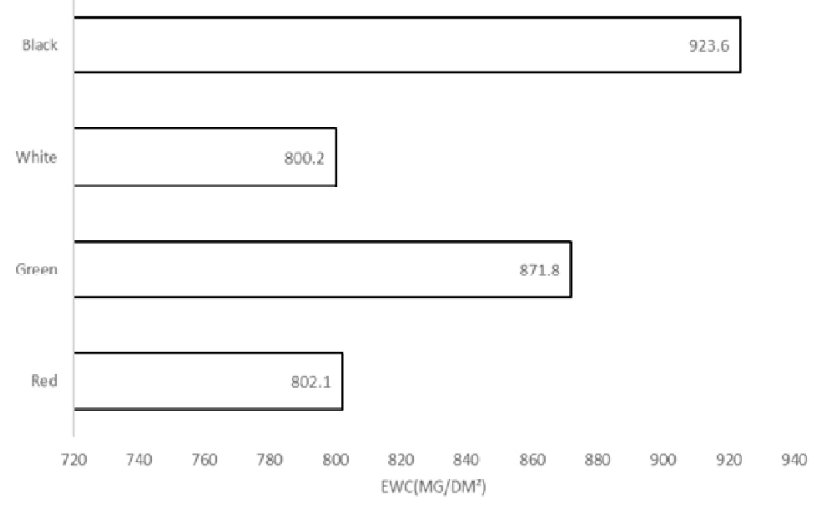

Fig. 5. Epicuticular foliage wax content of Philodendron 'Xanadu' cultivated under coloured shade nets

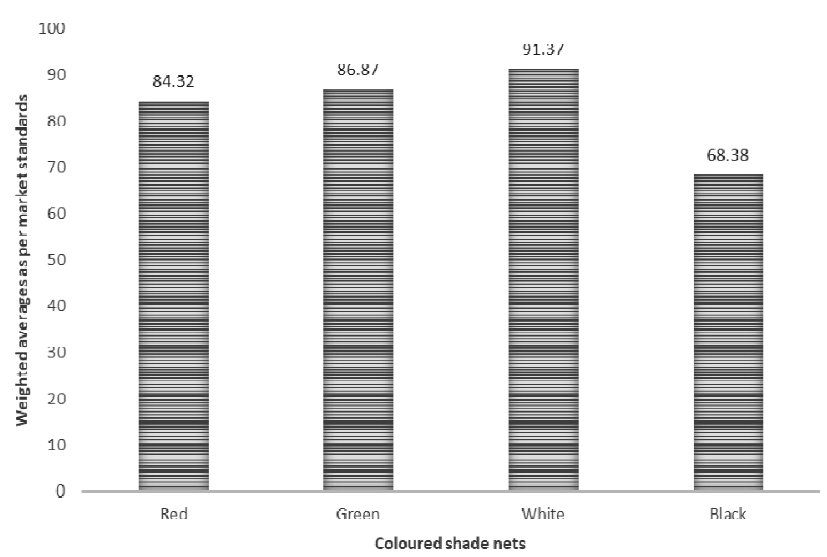

Fig. 6. Weighted averages for cut foliage of Philodendron 'Xanadu' cultivated under coloured shade nets

recorded during the months of January- February and PDI was $<5$ across all the shade net colours.

Among the different coloured shade nets, cultivation of Philodendron 'Xanadu' under the white shade net resulted in higher cut foliage production, whereas, the quality parameters and post-harvest keeping quality were on par with plants cultivated under green shade nets. The yield of cut foliage and quality attributes were higher during the rainy season compared to winter and summer. It can hence be concluded that, cultivation of Philodendron 'Xanadu'under white shade net (75\%) permitting light intensities ranging from 240.50 to $370 \mu \mathrm{mol} \mathrm{m} \mathrm{m}^{-2} \mathrm{~s}^{-1}$ maximised the cut foliage yield, quality and post harvest keeping quality. 


\section{REFERENCES}

Ahmad, M. and Cashmore, A. R. 1996. Seeing blue: The discovery of cryptochrome. Plant Molecular Biology, 30: 851-861

Ayala Tafoya, F., Juárez, M. G. Y., Orona, C. A. L., López, R. M., Alcaraz, T. J.V. and Valdés, T. D. 2018. Sunlight transmitted by colored shade nets on photosynthesis and yield of cucumber. Ciência Rural, Santa Maria, 48:09

Ayala Tafoya, F., Zatarain López, D. M., Valenzuela López, M. Partida Ruvalcaba, L. Velázquez Alcaraz, T. de J Díaz Valdés, T. and Osuna Sánchez, J. A. 2011. Growth and yield of tomato in response to sun radiation transmitted by shade nets. Terra Latinoamericana $\mathbf{2 9}$ (4):403-410

Batschauer, A. 1998. Photoreceptors of higher plants. Planta 206: 479-492

Cervelli, C., Castello, S. and Fadelli, P. G. 2003. Leaf distinctive features and production of leatherleaf fern grown in greenhouse under different shading levels. Acta Hortic. 614:521-526

Christie, J. M., and Jenkins, G. I. 1996. Distinct UV$\mathrm{B}$ and UV-A blue light signal transduction pathways induce chalcone synthase gene expression in Arabidopsis cells. Plant Cell, 8:1555-1567

Ganelevin, R.2008. World-wide commercial applications of colored shade nets technology (CHROMATINET®). Acta Hortic. 770: 199203

Gomez, K. A. and Gomez, A. A.1984. Statistical procedures for agricultural research $\left(2^{\text {nd }}\right.$ ed.) John Wiley and sons. New York.p. 680

Lobos, G. A., Retamales, J. B., Hancock, J. F., Flore, J. A., Cobo, N. and Pozo, A. 2012. Spectral irradiance, gas exchange characteristics and leaf traits of Vaccinium corymbosum L. 'Elliott' grown under photo-selective nets, Environmental and Experimental Botany, 75: 142-149

Medeiros, C.D., Falcão, H.M., Almeida-Cortez, J.D., Santos, Y.A.C., Oliveira, A.F.M. and Santos, M.G. 2017. Leaf epicuticular wax content changes under different rainfall regimes, and its removal affects the leaf chlorophyll content and gas exchanges of Aspidosperma pyrifolium in a seasonally dry tropical forest. South African J. Bot., 111: 267-274

Mohr, H.1994. Coaction between pigment systems. In: Kendrick R.E., Kronenberg G.H.M. (eds) Photomorphogenesis in Plants. Springer, Dordrecht: 353-373

Oliveira, G. C., Vieira, W. L., Bertolli, S. C. and Pacheco, A. C. 2016. Photosynthetic behavior, growth and essential oil production of Melissa officinalis L. cultivated under colored shade nets. Chilean J. Agric. Res. 76 (1):123-128

Shahak, Y.2008. Photo-selective netting for improved performance of horticultural crops. A review of ornamental and vegetable studies carried out in Israel. Acta Hortic. 770:161-168

Stamps, R. H. 2008. Differential effects of colored shade nets on three cut foliage crops. Acta Hortic. 770:169-176

Stuefer, J. F. and Huber, H. 1998.Differential effects of light quantity and spectral light quality on growth, morphology and development of two stoloniferous Potentilla species. Oecologia 117: $1-8$

Quail, P. H., Boylan, M. T., Parks, B. M., Short, T. W., Xu, Y., and Wagner, D. 1995. Phytochromes: Photosensory perception and signal transduction. Science, 268: 675-680

(Received on 20.12.2020; Revised on 30.05.2021; Accepted on 30.05.2021) 